\title{
Control of nuclear remodelling and subsequent in vitro development and methylation status of porcine nuclear transfer embryos
}

\author{
D J Kwon ${ }^{1}$, C K Park ${ }^{2}$, B K Yang ${ }^{2}$ and H T Cheong ${ }^{1,3}$ \\ ${ }^{1}$ School of Veterinary Medicine, ${ }^{2}$ College of Animal Life Sciences and ${ }^{3}$ Institute of Veterinary Science, Kangwon \\ National University, Chuncheon 200-701, South Korea
}

Correspondence should be addressed to H T Cheong; Email: htcheong@kangwon.ac.kr

\begin{abstract}
We attempted to control the nuclear remodelling of somatic cell nuclear transfer embryos (NTs) and examined their subsequent development and DNA methylation patterns in pigs. Porcine foetal fibroblasts were fused to enucleated oocytes treated with either $5 \mathbf{m M}$ caffeine for $2.5 \mathrm{~h}$ or $0.5 \mathrm{mM}$ vanadate for $0.5 \mathrm{~h}$. After activation, NTs were cultured in vitro for 6 days to examine their development. The nuclear remodelling type of the reconstituted embryos was evaluated $1 \mathrm{~h}$ after fusion. Methylated DNA of in vitro-fertilised (IVF) embryos and NTs at various developmental stages and of donor cells was detected using a 5-methylcytosine (5-MeC) antibody. Caffeine-treated NTs induced premature chromosome condensation at a high rate $(\boldsymbol{P}<\mathbf{0 . 0 5})$, whereas most vanadate-treated NTs formed a pronucleus-like structure. Although cleavage rates to the two-cell stage did not differ among groups, delayed cleavage was observed in the vanadate-treated group. The blastocyst formation rate was significantly reduced by vanadate treatment compared with caffeine-treated and non-treated (control) NT groups $(\boldsymbol{P}<0.05)$. The apoptotic cell index of NT blastocysts was lower in the caffeine-treated group than in other groups $(P<0.05)$. The methylation patterns were similar among NTs, but more hypermethylated DNA was observed at the four-cell stage of control and vanadate-treated NTs when compared with that in IVF embryos $(P<\mathbf{0 . 0 5})$. Thus, the nuclear remodelling type controlled by caffeine or vanadate treatment can affect in vitro development and the methylation status of NTs in relation to nuclear reprogramming.
\end{abstract}

Reproduction (2008) 135 649-656

\section{Introduction}

In nuclear transfer studies, the maturation promoting factor (MPF) in recipient oocytes is a critical factor regulating the nuclear remodelling of the transferred nucleus (Collas \& Robl 1991, Cheong et al. 1993). When a donor nucleus at the G0/G1 stage is transferred into a non-activated metaphase II (MII) oocyte, the high level of MPF activity causes nuclear envelope breakdown (NEBD) and a subsequent premature chromosome condensation (PCC) of the transferred nucleus (Collas \& Robl 1991, Tani et al. 2001). In contrast, a donor nucleus transferred into an activated recipient cytoplasm does not undergo NEBD and PCC, but forms a pronucleus-like structure (PN) because of the lower MPF activity (Szollosi et al. 1998, Tani et al. 2001).

A high MPF activity in mitotic cells induces NEBD via p34 ${ }^{\text {cdc2 }}$ kinase-related phosphorylation of lamin, which is a nuclear membrane protein (Peter et al. 1990). MPF is a serine/threonine protein kinase composed of p34 ${ }^{\text {cdc2 }}$ kinase and cyclin B (Hashimoto \& Kishimoto 1988); its activity can be controlled by the regulation of the phosphorylation state of $\mathrm{p} 34^{\mathrm{cdc} 2}$ at tyrosine- 15 (Y15) and threonine-14 (T14) residues (Norbury \& Nurse 1992,
Kikuchi et al. 2000). Caffeine suppresses phosphorylation at T14 and Y15 of the p34 ${ }^{\text {cdc2 }}$ kinase-cyclin B complex via the inhibition of Myt1/Wee1 activity, which causes an increase in MPF activity (Kikuchi et al. 2000). In contrast, vanadate suppresses cdc25 phosphatase activity, which induces phosphorylation at T14 and Y15 of the $\mathrm{p} 34^{\mathrm{cdc} 2}$ kinase-cyclin B complex, resulting in a reduction in the MPF activity (Kikuchi et al. 2000).

The nuclear remodelling of a transferred nucleus might play an important role in the subsequent development of NTs (Collas \& Robl 1991, Cheong et al. 1993, Kim et al. 2002). It is thought that NEBD is a critical step in the reprogramming of differentiated nuclei by allowing the direct interaction of chromosomes with cytoplasmic factors in non-activated oocytes (Wakayama et al. 1998, Tani et al. 2001, Kim et al. 2002). Nevertheless, when a donor nucleus is transferred into a non-activated recipient cytoplasm, some of the introduced nuclei form PNs without undergoing NEBD because of simultaneous activation by fusion pulse (Cheong et al. 2002); these develop to the blastocyst stage and to term (Campbell et al. 1996, Kurosaka et al. 2002, Bordignon et al. 2003). Thus, even though the 
direct exposure of chromosomes to the cytoplasm is thought to be important for the reprogramming of chromatin to support embryo development, a direct comparison of development in NTs that have PCC or PN has not been made in pigs.

Hence, we attempted to control nuclear remodelling by treating porcine recipient oocytes with caffeine or vanadate and examined the subsequent in vitro development, apoptosis, and DNA methylation patterns of somatic cell NTs.

\section{Results}

Effects of caffeine and vanadate on cdc2 kinase activity

The effects of caffeine and vanadate on cdc2 kinase activity in enucleated porcine oocytes differed. Caffeine treatment resulted in a high cdc2 kinase activity (Fig. 1). In contrast, vanadate treatment resulted in a significantly lower cdc2 kinase activity than that in the caffeinetreated and control groups $(P<0.05 ;$ Fig. 1$)$.

\section{Effects of caffeine and vanadate on the development of parthenotes}

Caffeine and vanadate did not affect the development of porcine parthenotes. There were no significant differences in the rates of cleavage (84.9-86.6\%), fragmentation (15.1-21.0\%), blastocyst formation $(26.6-33.8 \%)$ or the number of cells in blastocysts among the control, vanadate-treated and caffeinetreated groups (Table 1).

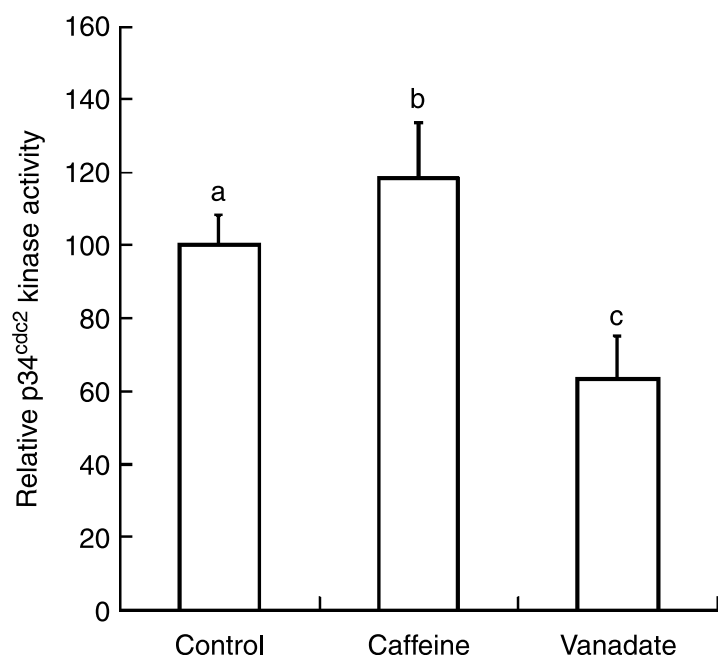

Figure 1 Effects of caffeine and vanadate on the activity of p34 $4^{\mathrm{cdc} 2}$ kinase in enucleated porcine oocytes. All MII oocytes were enucleated $42 \mathrm{~h}$ after maturational culture and the p3 $4^{\mathrm{cdc} 2}$ kinase activity in control, caffeine-treated and vanadate-treated groups was analysed at the same time after enucleation $(n=20 \times 3$ trials for each group). The activity level in enucleated oocytes was defined as $100 \%$. Data are expressed as relative $\mathrm{p} 34^{\mathrm{cdc} 2}$ activity. Error bars indicate \pm S.E.M. ${ }^{\mathrm{a}-\mathrm{c}}$ Different letters indicate significant differences $(P<0.05)$.

\section{Effects of caffeine and vanadate on the remodelling pattern of NTs}

The remodelling pattern of the donor nuclei transferred into the recipient oocytes treated with caffeine or vanadate differed. Caffeine treatment resulted in a higher occurrence of PCC $(81.3 \%, P<0.05)$, whereas vanadate treatment induced the formation of a $\mathrm{PN}$ at a higher frequency $(89.0 \%, P<0.05$; Table 2$)$.

\section{Effects of caffeine and vanadate on the development of NTs}

The cleavage rate $(71.1-83.3 \%)$ and the number of cells in blastocysts $(23.0 \pm 3.3-28.6 \pm 2.6)$ did not differ among caffeine-treated, vanadate-treated and control groups (Table 3 ). The rates of fragmentation and development to the blastocyst stage of NTs derived from caffeine-treated recipients were not different from those of control embryos (15.3\% vs $13.1 \%$ and $31.3 \%$ vs $28.3 \%$ respectively), whereas the fragmentation rate of NTs increased significantly (to $27.5 \% ; P<0.05$ ) and the blastocyst formation rate declined significantly (to $16.5 \%$ ) when the recipient oocytes were treated with vanadate (Table 3 ).

The number of apoptotic cells in blastocysts from NTs treated with caffeine was significantly lower $(P<0.05)$ than those of the control and the vanadate-treated groups, whereas there was no difference in the number of apoptotic cells between the control and the vanadatetreated groups (Fig. 2).

\section{Effects of caffeine and vanadate on the cleavage timing of NTs}

The treatment of recipient oocytes with vanadate resulted in a significantly lower percentage of cleaved embryos at $20 \mathrm{~h}(27.9 \%, P<0.05)$ than in the control $(55.2 \%)$ and caffeine-treated groups (48.6\%). However, caffeine or vanadate treatment had no effect on the formation rate of total cleaved embryos at $48 \mathrm{~h}(66.7-78.5 \%$; Fig. 3).

\section{Effects of caffeine and vanadate on the methylation status of porcine NTs}

There was no difference in the methylation status at the one-cell stage among the in vitro fertilisation (IVF) and NT embryo groups (53.0-67.2\%), and their methylation status $(56.0 \%)$ was similar to that of donor cells (Figs 4 and 5). The methylation level of IVF embryos decreased dramatically from the one- to four-cell stage $(58.0-21.1 \%)$, and the decline continued through the morula (25.3\%) and the blastocyst stages (14.9\%; Fig. 5). The demethylation pattern was similar among NT groups at various developmental stages. However, hypermethylated DNA was observed at the four-cell stage in the control and vanadate-treated NT groups when compared 
Table 1 Effects of caffeine and vanadate on the development of porcine parthenotes.

\begin{tabular}{|c|c|c|c|c|c|}
\hline \multirow[b]{2}{*}{ Treatment } & \multirow[b]{2}{*}{ Number of oocytes } & \multicolumn{3}{|c|}{ Number of embryos (\%) } & \multirow{2}{*}{$\begin{array}{c}\text { Number of cells in blastocysts } \\
(\text { mean } \pm \text { s.E.M. })\end{array}$} \\
\hline & & Two-cell & Fragment & Blastocyst & \\
\hline Control & 152 & $129(84.9)$ & $23(15.1)$ & $46(30.3)$ & $24.4 \pm 2.3$ \\
\hline Caffeine & 157 & 136 (86.6) & $33(21.0)$ & 53 (33.8) & $26.6 \pm 1.4$ \\
\hline Vanadate & 158 & $135(85.4)$ & $32(20.3)$ & $42(26.6)$ & $25.2 \pm 1.8$ \\
\hline
\end{tabular}

with the IVF group (38.5 and $34.8 \%$ vs $21.1 \% ; P<0.05$; Fig. 5). The methylation status of morulae and blastocysts was comparable among groups.

\section{Discussion}

To determine which nuclear remodelling type (either $\mathrm{PCC}$ or PN) is more appropriate for the reprogramming of a transferred nucleus at the G0/G1 stage, we examined the development and quality of NTs in which different remodelling types were induced using caffeine or vanadate.

When a donor nucleus was transferred into a recipient oocyte treated with caffeine, most of them underwent NEBD and subsequently induced PCC, which might have been caused by the increased activity of $\mathrm{p} 34^{\text {cdc2 }}$ kinase. The amount of MPF activity that is needed to cause NEBD of the transferred nucleus is unclear, but our results indicate that increasing the MPF activity in porcine oocytes by treatment with $5 \mathrm{mM}$ caffeine for more than $2.5 \mathrm{~h}$ can induce NEBD and PCC (Ito et al. 2005, Lee \& Campbell 2006). In contrast, when a donor nucleus was exposed to a recipient cytoplasm treated with vanadate, NEBD did not occur and the transferred nucleus formed a PN. When MII oocytes were treated with $0.5 \mathrm{mM}$ vanadate for $0.5 \mathrm{~h}$, morphological changes such as the resumption of meiosis or the formation of a $\mathrm{PN}$ were not observed for at least $3 \mathrm{~h}$ after treatment (data not shown). Furthermore, the development of vanadate-treated parthenotes was similar to that of the caffeine-treated and control groups. Thus, vanadate did not induce oocyte activation and had no deleterious effect on embryo development. These results indicate that the remodelling type of a transferred nucleus can be controlled without any deleterious effects using caffeine and vanadate to regulate $\mathrm{p} 34^{\mathrm{cdc} 2}$ kinase activity in the recipient cytoplasm.

In the case of porcine NTs, the developmental rate during the preimplantation stage or the total number of cells in the blastocyst stage increases when a donor nucleus is injected into a caffeine-treated recipient (Kawahara et al. 2005, Lee \& Campbell 2006). The higher total number of cells or developmental capability is thought to occur in PCC because of increased MPF activity in the recipient cytoplasm, rather than the caffeine treatment itself. Tani et al. (2003) suggested that MPF activity itself does not directly regulate the nuclear reprogramming of somatic cell nuclei, but the exposure of donor chromosomes to an oocyte cytoplasm is important for the occurrence of essential events for the donor nuclei at the G0/G1 stage to be reprogrammed. Thus, the use of recipient cytoplasts with a high MPF activity to induce the PCC of a donor nucleus at the G0/G1 stage seems to be an effective way to ensure the appropriate reprogramming of a differentiated donor nucleus. However, a contrasting suggestion was recently made in cattle, in which a donor nucleus that was exposed to a recipient cytoplasm that had high MPF activity by simultaneous activation for a very short time directly developed a PN and supported a high blastocyst development of NTs (Sung et al. 2007). The reason for these differences is unclear, but might be due to differences in the ability of bovine and porcine oocytes to remodel or reprogramme the transferred nucleus (Yin et al. 2003, Kawahara et al. 2005, Sung et al. 2007).

Although the total cleavage rate of the vanadatetreated group was similar to those of the control and caffeine-treated groups, the duration of interphase in the

Table 2 Effects of caffeine and vanadate on the remodelling pattern of porcine NTs ${ }^{*}$.

\begin{tabular}{|c|c|c|c|c|c|c|c|c|}
\hline \multirow[b]{3}{*}{ Treatment } & \multirow[b]{3}{*}{ Number of NTs } & \multicolumn{7}{|c|}{ Number of eggs (\%) } \\
\hline & & \multicolumn{3}{|c|}{ PCC } & \multirow[b]{2}{*}{ Total } & \multicolumn{2}{|c|}{ NPCC } & \multirow[b]{2}{*}{ Total } \\
\hline & & M-plate & $1 \mathrm{C}$ & $\geq 2 \mathrm{C}$ & & $1 \mathrm{PN}$ & $2 \mathrm{PN}$ & \\
\hline Control & 80 & $8(10.0)^{\mathrm{a}}$ & $32(40.0)^{\mathrm{a}}$ & $4(5.0)$ & $44(55.0)^{\mathrm{a}}$ & $35(43.8)^{\mathrm{a}}$ & $1(1.3)$ & $36(45.0)^{\mathrm{a}}$ \\
\hline Caffeine & 112 & $25(22.3)^{\mathrm{b}}$ & $64(57.1)^{b}$ & $2(1.8)$ & $91(81.3)^{b}$ & $21(18.8)^{b}$ & - & $21(18.8)^{b}$ \\
\hline Vanadate & 100 & $2(2.0)^{\mathrm{C}}$ & $8(8.0)^{\mathrm{c}}$ & $1(1.0)$ & $11(11.0)^{\mathrm{c}}$ & $89(89.0)^{\mathrm{C}}$ & - & $89(89.0)^{\mathrm{C}}$ \\
\hline
\end{tabular}

${ }_{a, b, c}$ Different letters indicate significant differences within columns $(P<0.05)$.

${ }^{*}$ The morphological status of the nucleus was examined $1 \mathrm{~h}$ after fusion. PCC, premature chromosome condensation; M-plate, metaphase chromosome plate; $\mathrm{C}$, condensed chromatin clump; NPCC, non-PCC; PN, pronucleus-like structure. 
Table 3 Effects of caffeine and vanadate on the development of porcine NTs.

\begin{tabular}{|c|c|c|c|c|c|}
\hline \multirow[b]{2}{*}{ Treatment } & \multirow[b]{2}{*}{ Number of NTs } & \multicolumn{3}{|c|}{ Number of embryos (\%) } & \multirow{2}{*}{$\begin{array}{l}\text { Number of cells in blastocysts } \\
(\text { mean } \pm \text { S.E.M. })\end{array}$} \\
\hline & & Two-cell & Fragment & Blastocyst & \\
\hline Control & 145 & $111(76.6)$ & $19(13.1)^{\mathrm{a}}$ & $41(28.3)^{\mathrm{a}}$ & $25.8 \pm 3.0$ \\
\hline Caffeine & 144 & $120(83.3)$ & $22(15.3)^{\mathrm{a}}$ & $45(31.3)^{\mathrm{a}}$ & $28.6 \pm 2.6$ \\
\hline Vanadate & 218 & $155(71.1)$ & $60(27.5)^{b}$ & $36(16.5)^{\mathrm{b}}$ & $23.0 \pm 3.3$ \\
\hline
\end{tabular}

${ }^{\mathrm{a}, \mathrm{b}}$ Different letters indicate significant differences within columns $(P<0.05)$.

first cell cycle was prolonged (Fig. 2), which might have eventually led to an inopportune cleavage. Furthermore, low developmental frequency was observed in the vanadate-treated group. It is possible that this delayed first cleavage is caused by a checkpoint mechanism that results from the incomplete reprogramming of donor materials. If one of the mitotic events that is monitored by a checkpoint (Rudner \& Murray 1996) does not completely or exactly occur, the cell division is arrested until the process is executed successfully, which might eventually lead to apoptosis or programmed cell death (Hengartner 2000). Another possibility is that a much longer time is required to reprogramme the nucleus that is formed in a PN without NEBD when compared with that required for a nucleus that underwent PCC in porcine NTs, which might affect further development or epigenetic modification in the preimplantation stage.

The early developmental ability, number of cells and apoptotic cell index in the blastocyst, and DNA methylation status might serve as indicators of the occurrence of appropriate epigenetic reprogramming

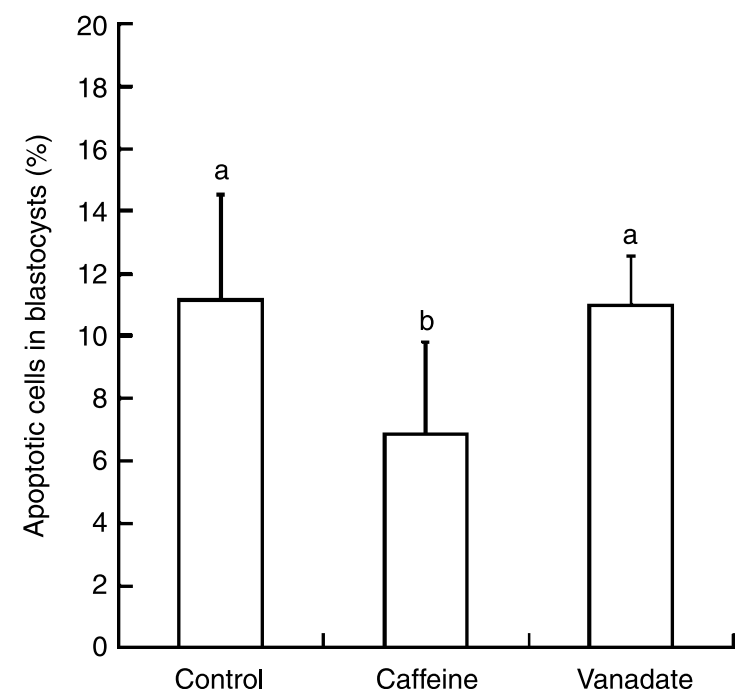

Figure 2 Apoptotic cell index in blastocysts derived from NTs. The apoptotic cell index (TUNEL-positive cells/total cells in blastocysts) at day 6 after culture is presented for the control $(52 / 465, n=19)$, caffeinetreated $(36 / 525, n=20)$ and vanadate-treated $(28 / 255, n=13)$ groups. Error bars indicate \pm s.E.M. ${ }^{\mathrm{a}, \mathrm{b}}$ Different letters indicate significant differences $(P<0.05)$. in somatic cell NTs. DNA demethylation in embryos relative to their developmental stage is very important to ensure normal embryonic development, hence aberrant methylation status or demethylation patterns of embryos during the preimplantation stages can lead to a developmental failure (Shi \& Haaf 2002, Beaujean et al. 2004). It is possible that embryos that developed to the blastocyst stage received sufficient epigenetic modification for early development. This possibility is explained by a previous research in which abnormal methylation at the two-cell stage in the mouse is correlated with embryo loss during the preimplantation period (Shi \& Haaf 2002). Our results show similarity in the demethylation patterns of morulae and blastocysts in NT and IVF embryos, regardless of differences in their developmental frequency. The methylation pattern of cloned porcine embryos (Kang et al. 2001b), as an epigenetic reprogramming marker, might differ from that of other species such as those previously reported in mouse (Dean et al. 2001), sheep (Beaujean et al. 2004) and cattle (Kang et al. 2001a). Even though the rate of embryos showing PCC was higher than that of the control, preimplantation development and the total

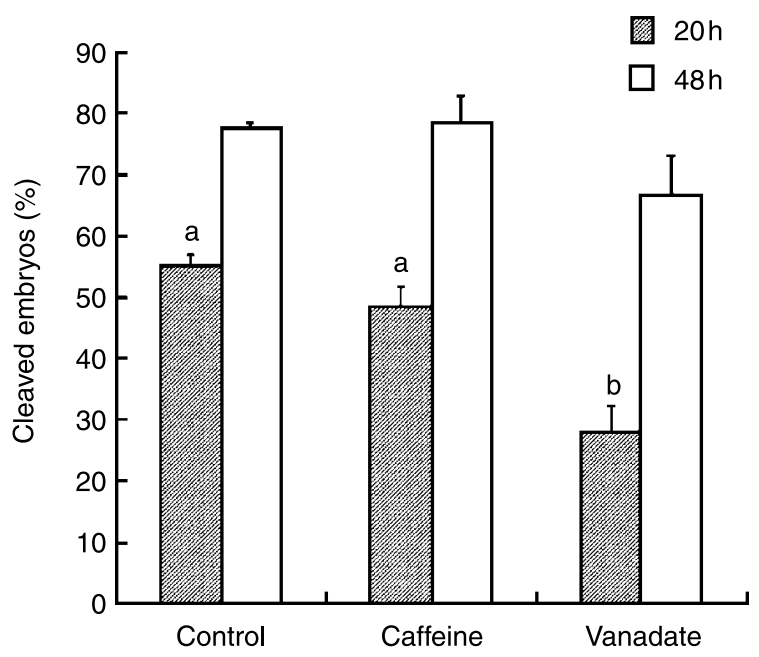

Figure 3 Effects of caffeine and vanadate on the timing of cleavage in porcine NTs. The cleavage rate at 20 and $48 \mathrm{~h}$ of culture is presented for the control $(n=67)$, caffeine-treated $(n=107)$ and vanadate-treated $(n=129)$ groups. Error bars indicate \pm s.E.M. ${ }^{\mathrm{a}, \mathrm{b}}$ Different letters indicate significant differences $(P<0.05)$. 

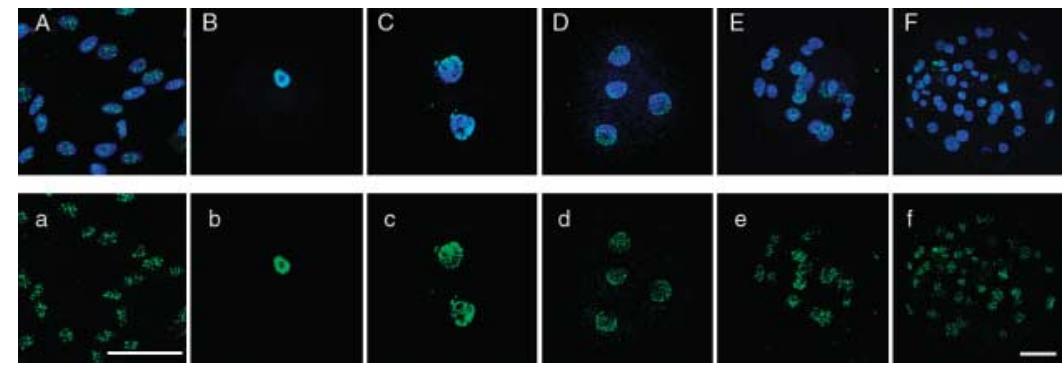

Figure 4 Normal methylation patterns in donor cells (A and a) and NT embryos at various developmental stages (B-F and b-f). Nucleus (blue) and 5-MeC (green; $a-f$ ) were visualised using laser scanning confocal microscopy. A-F are merged images. Scale bars indicate $50 \mu \mathrm{m}$. number of cells in blastocysts were not increased by caffeine treatment. However, the apoptotic cell index in blastocysts from the caffeine-treated group was lower than those in the control and vanadate-treated groups, and only the caffeine-treated group had a DNA methylation pattern at the four-cell stage that was similar to that of IVF. At this stage, genomic activation and genome-wide transcription occur in porcine embryos, but we cannot assert that transcription in a donor genome that efficiently receives global demethylation occurs at genomic loci related to further embryonic development or apoptosis, because the relationship between the global demethylation level and the expression of specific sequences cannot be determined using the immunostaining method used here. Interestingly, a high level of prothymosin $\alpha$, which is related to the protection from apoptotic damage (Evstafieva et al. 2003), is observed at this stage through transcriptional profiling (Whitworth et al. 2005). These observations can explain the low apoptotic cell index in the caffeinetreated group. Caffeine can protect cells from apoptotic damage by the induction of normal methylation in early embryos, which might be related to the occurrence of PCC.

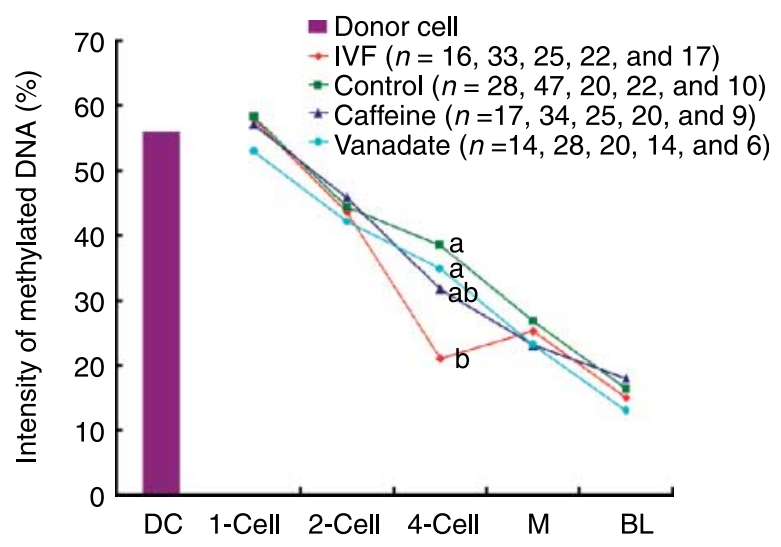

Figure 5 The methylation status at the various developmental stages in IVF and NT embryos. The methylation intensity in IVF and NT embryos at various developmental stages are presented as methylated DNA/total DNA intensity. DC, donor cell; M, morula; BL, blastocyst; ' $n$ ' is the number of embryos corresponding to each treatment and stage. ${ }^{a, b}$ Different letters indicate significant differences within a stage $(P<0.05)$.
In conclusion, we demonstrated that the morphological remodelling type of NTs reconstructed using donor cells at the G0/G1 stage can be controlled by treatment with the MPF regulators, caffeine and vanadate. Furthermore, PCC appeared to be a more suitable nuclear remodelling type to reprogramme transferred nuclei at the G0/G1 stage because NTs that had a nucleus that underwent PCC were characterised by efficient demethylation and low apoptosis. In contrast, NTs that had a PN without PCC were characterised by a prolonged interphase in the first cell cycle and a low developmental capability.

\section{Materials and Methods}

\section{In vitro maturation of oocytes}

Porcine ovaries were collected from a slaughterhouse. Cumulus-oocyte complexes (COCs) were collected from antral follicles 3-6 mm in diameter and washed in Tyrode's lactateHEPES containing $0.1 \%(\mathrm{w} / \mathrm{v})$ polyvinyl alcohol (PVA; Sigma). For maturation culture, $\sim 50-100$ COCs were cultured in a $500 \mu \mathrm{l}$ drop of NCSU-23 medium (Petters \& Wells 1993) supplemented with $0.6 \mathrm{mM}$ cysteine (Sigma), $10 \mathrm{IU} / \mathrm{ml}$ pregnant mare's serum gonadotrophin (PMSG; Intervet International BV, Boxmeer, Holland), $10 \mathrm{lU} / \mathrm{ml}$ human chorionic gonadotrophin (hCG; Intervet International BV), $10 \mathrm{ng} / \mathrm{ml}$ epidermal growth factor (EGF; Sigma), $10 \%(\mathrm{v} / \mathrm{v})$ porcine follicular fluid and $50 \mu \mathrm{g} / \mathrm{ml}$ gentamicin (Sigma), covered with paraffin oil and incubated at $39^{\circ} \mathrm{C}$ in a humidified atmosphere of $5 \% \mathrm{CO}_{2}$ in air for $22 \mathrm{~h}$. COCs were then cultured in the same medium without hormones for $20 \mathrm{~h}$. After maturation, the cumulus cells were removed by vortexing the COCs in PBS (Gibco-BRL) containing $0.1 \%$ PVA and $0.1 \%$ hyaluronidase (Sigma).

\section{In vitro fertilisation (IVF)}

Oocytes were washed thrice in modified Tris-buffered medium containing $113 \mathrm{mM} \mathrm{NaCl}, 3 \mathrm{mM} \mathrm{KCl}, 7.5 \mathrm{mM} \mathrm{CaCl} \cdot 2 \mathrm{H}_{2} \mathrm{O}$, $20 \mathrm{mM}$ Tris, $5 \mathrm{mM}$ sodium pyruvate (Sigma), $11 \mathrm{mM}$ glucose, $2 \mathrm{mM}$ caffeine (Sigma) and $2 \mathrm{mg} / \mathrm{ml} \mathrm{BSA}$ (IVF medium). Ten to fifteen oocytes were transferred into a $45 \mu \mathrm{l}$ droplet of IVF medium overlaid with paraffin oil. Fresh semen collected from boars at an artificial insemination centre was centrifuged twice at $1900 \mathrm{~g}$ for $4 \mathrm{~min}$. The spermatozoa were resuspended in IVF medium at a sperm concentration of $1 \times 10^{6}$ cell $\mathrm{s} / \mathrm{ml}$. Finally, $5 \mu \mathrm{l}$ of the sperm suspension was added to each 
droplet and cultured at $39{ }^{\circ} \mathrm{C}$ in a humidified atmosphere of $5 \%$ $\mathrm{CO}_{2}$ in air for $6 \mathrm{~h}$.

\section{Enucleation of oocytes and treatment with caffeine and vanadate}

The enucleation of oocytes was carried out in HEPES-buffered TCM-199 (Gibco-BRL) supplemented with $3 \mathrm{mg} / \mathrm{ml}$ BSA and $5 \mu \mathrm{g} / \mathrm{ml}$ cytochalasin B (CB; Sigma). Enucleation was confirmed by staining the oocytes with $1 \mu \mathrm{g} / \mathrm{ml}$ Hoechst 33342 (Sigma) at $39{ }^{\circ} \mathrm{C}$ for $15-20 \mathrm{~min}$. Enucleated oocytes were treated with caffeine or vanadate to increase or decrease, the MPF activity before the injection of a donor cell, by culturing them in TCM199 containing $3 \mathrm{mg} / \mathrm{ml} \mathrm{BSA}$ and $5 \mathrm{mM}$ caffeine (Sigma) or $0.5 \mathrm{mM}$ vanadate (Sigma) for 2.5 or $0.5 \mathrm{~h}$ respectively (Kikuchi et al. 2000). Twenty enucleated oocytes of each treatment, i.e. caffeine, vanadate and untreated control, were assessed for MPF kinase activity (three replicates per treatment). Mature oocytes were also treated with the same chemicals before parthenogenetic activation and in vitro culture to evaluate the effects of these chemicals on embryo development.

\section{MPF kinase assay}

The MPF kinase assay was conducted by measuring the activity of its catalytic subunit, cdc2 kinase, using a MESACUP cdc2 kinase assay kit (MBL, Nagoya, Japan), as described by Anas et al. (2000). Briefly, enucleated oocytes were washed twice with the cdc2 kinase sample buffer and then stored frozen at $-80^{\circ} \mathrm{C}$. At the time of the assay, oocytes were lysed by successive freezing and thawing in liquid nitrogen and water respectively. Oocyte extracts were mixed with kinase assay buffer and incubated at $30{ }^{\circ} \mathrm{C}$ for $30 \mathrm{~min}$. The phosphorylation reaction was terminated using a stop reagent, and the solution was centrifuged at $13000 \mathrm{~g}$ for $15 \mathrm{~s}$. For the detection of cdc2 kinase using ELISA, each of the reaction mixture was transferred into a microwell strip coated with $M A B$ recognising the phosphorylated form of the biotinylated MV peptide (SerLue-Tyr-Ser-Ser-Ser-Pro-Gly-Gly-Ala-Tyr-Cys). The microwells were incubated at $25^{\circ} \mathrm{C}$ for $60 \mathrm{~min}$ and then washed five times with a washing solution. Horseradish peroxidase (POD)conjugated streptavidin solution was added to each well and incubated at $25^{\circ} \mathrm{C}$ for $30 \mathrm{~min}$. After washing, the POD substrate solution was added and incubated for an additional 5 min. Finally, a stop solution was added to each well, and the optical density was read at $492 \mathrm{~nm}$ using a microplate reader.

\section{Nuclear transfer, electrofusion and activation}

Nuclear transfer was carried out in HEPES-buffered TCM-199 (Gibco-BRL) supplemented with $3 \mathrm{mg} / \mathrm{ml} \mathrm{BSA}$ and $5 \mu \mathrm{g} / \mathrm{ml} \mathrm{CB}$. Donor cells were obtained from a day 50 crossbred female porcine foetus. Cells were cultured in Dulbecco's modified Eagle's medium (DMEM; Gibco-BRL) supplemented with 10\% foetal bovine serum (FBS; Gibco-BRL) and $50 \mu \mathrm{g} / \mathrm{ml}$ gentamicin for 2-3 days. Before NT, cells were further cultured in DMEM supplemented with $0.5 \%$ FBS for 5 days to synchronise the cell cycle at the G0/G1 phase. The cell cycle stage was determined by flow cytometry, which showed that $95.4 \pm 3.2 \%$ (mean \pm s.D.) of the foetal fibroblast cells were in G0/G1 (Supplementary Data, which can be viewed online at www. reproduction-online.org/supplemental/). A single cell with a smooth surface was transferred into the perivitelline space of an enucleated oocyte. For the caffeine- or vanadate-treated enucleated oocytes, donor cells were transferred within $0.5 \mathrm{~h}$ after the release from these chemicals.

Reconstituted oocytes were fused immediately after the injection of donor cells for the caffeine- or vanadate-treated groups and after $1 \mathrm{~h}$ of culture for the untreated control group. Reconstituted oocytes were placed between $0.2 \mathrm{~mm}$ diameter wire electrodes ( $1 \mathrm{~mm}$ apart) in a fusion chamber overlaid with $0.3 \mathrm{M}$ mannitol (Sigma) solution containing $0.1 \mathrm{mM} \mathrm{MgSO}_{4}$ (Sigma), $0.5 \mathrm{mM} \mathrm{CaCl}_{2}$ (Sigma) and $3 \mathrm{mg} / \mathrm{ml} \mathrm{BSA}$. For fusion, a single DC pulse of $150 \mathrm{~V} / \mathrm{mm}$ was applied for $30 \mu$ s using a BTX Electro Cell Manipulator 200 (BTX, San Diego, CA, USA). After fusion treatment, the reconstituted oocytes were held in TCM-199 supplemented with $3 \mathrm{mg} / \mathrm{ml}$ BSA for $1 \mathrm{~h}$ and checked for fusion. The fused embryos were further activated $1 \mathrm{~h}$ after the fusion treatment by exposure to two DC pulses of $100 \mathrm{~V} / \mathrm{mm}$ for $50 \mu \mathrm{s}$, followed by treatment with $2 \mathrm{mM}$ of 6-dimethlyaminopurine (6-DMAP; Sigma) for $4 \mathrm{~h}$ before in vitro culture. Parthenogenetic embryos (parthenotes) were produced by exposing oocytes to the same electrical pulses and chemicals as those used for the reconstituted oocytes.

\section{Evaluation of nuclear remodelling type}

One hour after fusion, the reconstituted embryos were fixed in a mixture of acetic acid and ethanol (3:1) for $\sim 48 \mathrm{~h}$ and stained with $1 \%$ aceto-orcein. The transferred nucleus showing a condensed chromatin clump or chromosome plate was determined to be PCC and that showing a PN was determined to be non-PCC (NPCC; Cheong et al. 1994).

\section{In vitro culture of embryos}

IVF, NT and parthenogenetic embryos were cultured in $50 \mu \mathrm{l}$ droplets of PZM-3 (Yoshioka et al. 2002) supplemented with $3 \mathrm{mg} / \mathrm{ml}$ BSA and overlaid with paraffin oil under an atmosphere of $5 \% \mathrm{CO}_{2}$ in humidified air at $39{ }^{\circ} \mathrm{C}$ for 6 days. At 20 and $48 \mathrm{~h}$ of culture, the embryos were examined for cleavage. At Day 6 of culture, the embryos were examined for development to the blastocyst stage. After 6 days of in vitro culture, the number of apoptotic cells in blastocysts was checked. At $18 \mathrm{~h}$ and 2, 3, 5 and 6 days of culture, one-, twoand four-cell embryos, morulae and blastocysts were fixed for the detection of methylated DNA respectively.

\section{Examination of apoptotic cells in blastocysts}

A TUNEL assay was used to examine the number of apoptotic cells in blastocysts from NTs. Blastocysts were fixed in PBS containing $3.7 \%(\mathrm{w} / \mathrm{v})$ paraformaldehyde for $1 \mathrm{~h}$ and permeabilised in $0.5 \%$ Triton X-100 solution at room temperature for $30 \mathrm{~min}$. The fixed blastocysts were incubated in the TUNEL reaction medium (in situ cell death detection kit, TMR red; Roche) in darkness at $39{ }^{\circ} \mathrm{C}$ for $1 \mathrm{~h}$. The broken DNA ends of the blastomere were labelled with TdT and fluorescein-dUTP. 
For counterstaining of DNA, the blastocysts were incubated in $1 \mu \mathrm{g} / \mathrm{ml}$ Hoechst 33342 at $39^{\circ} \mathrm{C}$ for 30 min and then mounted on glass slides in Vecta-Shield anti-fade (Vector Laboratories, Burlingame, CA, USA) under a cover slip. The number of apoptotic nuclei and the total number of nuclei were determined using a fluorescence microscope.

\section{Immunodetection of DNA methylation}

IVF and NT embryos at various developmental stages (one- to four-cell, morula and blastocyst) and donor cells were washed with $0.05 \%$ Tween 20 in PBS (in all cases, sample washing was performed before further processing), fixed in $4 \%$ paraformaldehyde in PBS for 15 min and permeabilised with $0.2 \%$ Triton $X-100$ in PBS at room temperature for 15 min. For the detection of 5-methylcytosine (5-MeC), embryos and donor cells were treated with $2 \mathrm{M} \mathrm{HCl}$ at room temperature for $30 \mathrm{~min}$ and subsequently neutralised for $10 \mathrm{~min}$ with $100 \mathrm{mM}$ Tris/ $\mathrm{HCl}$ buffer ( $\mathrm{pH} \mathrm{8.5).} \mathrm{Embryos} \mathrm{and} \mathrm{donor} \mathrm{cells} \mathrm{were} \mathrm{then} \mathrm{blocked}$ overnight at $4{ }^{\circ} \mathrm{C}$ using PBS containing $1 \%$ BSA and $0.05 \%$ Tween 20. For the immunostaining of methylated DNA, embryos and donor cells were sequentially incubated with a $20 \mu \mathrm{g} / \mathrm{ml}$ mouse MAB against 5-MeC (Calbiochem, San Diego, CA, USA) and a Alaxa-488 goat anti-mouse IgG (1:200 dilution; Molecular Probes, Eugene, OR, USA) at $39^{\circ} \mathrm{C}$ for $1 \mathrm{~h}$ and $40 \mathrm{~min}$ respectively. DNA was stained with $3 \mu \mathrm{g} / \mathrm{ml}$ 4,6-diamidino-2-phenylindole (Sigma) for $20 \mathrm{~min}$. The embryos and donor cells were mounted on glass slides in Vecta-Shield anti-fade (Vector Laboratories). Z-stack images were obtained by sequential scanning of the sample at $1-\mu \mathrm{m}$ intervals using the LSM 510 Meta NLO microscope (Zeiss, Jena, Germany) and merged with the Zeiss LSM image browser (ver. 3.2.0.70). The same pinhole, gain and offset were used for each experiment. Each nucleus in each embryo was outlined manually, and the fluorescence intensity emitted by each nucleus was measured using ImageJ 1.37v (National Institutes of Health, Bethesda, MD, USA) and averaged per embryo.

\section{Statistical analysis}

At least three replicates were performed for each treatment. The percentages of embryo fragmentation and development, number of cells and methylation data were analysed using Duncan's multiple range tests, using the general linear model procedure in SAS (SAS Institute, Inc., Cary, NC, USA). The remodelling type of NTs and number of apoptotic cells in blastocysts were analysed by $\chi^{2}$-test.

\section{Acknowledgements}

We thank Seung-Hae Kwon of the South Korea Basic Science Institute, Chuncheon, Korea, for expert assistance with confocal microscopy. This work was supported by a Korea Research Foundation Grant, funded by the Korean Government (MOEHRD) (KRF-2005-042-F00030). The authors declare that there is no conflict of interest that would prejudice the impartiality of this scientific work.

\section{References}

Anas MKI, Shoho A, Shimada M \& Terada T 2000 Effects of wortmannin on the kinetics of GVBD and the activities of the maturation-promoting factor and mitogen-activated protein kinase during bovine oocyte maturation in vitro. Theriogenology 53 1797-1806.

Beaujean N, Taylor J, Gardner J, Wilmut I, Meehan R \& Young L 2004 Effect of limited DNA methylation reprogramming in the normal sheep embryo on somatic cell nuclear transfer. Biology of Reproduction 71 185-193.

Bordignon V, Keyston R, Lazaris A, Bilodeau AS, Pontes JH, Arnold D, Fecteau G, Keefer C \& Smith LC 2003 Transgene expression of green fluorescent protein and germ line transmission in cloned claves derived from in vitro-transfected somatic cells. Biology of Reproduction 68 2013-2023.

Campbell KHS, McWhir J, Ritchie W \& Wilmut I 1996 Live lambs by nuclear transfer from an established cultured cell line. Theriogenology 45287.

Cheong HT, Takahashi Y \& Kanagawa H 1993 Birth of mice after transplantation of early cell-cycle-stage embryonic nuclei into enucleated oocytes. Biology of Reproduction 48 958-963.

Cheong HT, Takahashi Y \& Kanagawa H 1994 Relationship between nuclear remodeling and subsequent development of mouse embryonic nuclei transferred to enucleated oocytes. Molecular Reproduction and Development 37 138-145.

Cheong HT, Park KW, Im GS, Lai L, Sun Q-Y, Day BN \& Prather RS 2002 Effect of elevated $\mathrm{Ca}^{2+}$ concentration in fusion/activation medium on the fusion and development of porcine fetal fibroblast nuclear transfer embryos. Molecular Reproduction and Development 61 488-492.

Collas P \& Robl JM 1991 Relationship between nuclear remodeling and development in nuclear transplant rabbit embryos. Biology of Reproduction 45 455-465.

Dean W, Santos F, Stojkovic M, Zakhartchenko V, Walter J, Wolf E \& Reik W 2001 Conservation of methylation reprogramming in mammalian development: aberrant reprogramming in cloned embryos. PNAS 98 13734-13738.

Evstafieva AG, Belov GA, Rubtsov YP, Kalkum M, Joseph B, Chichkova NV, Sukhacheva EA, Bogdanov AA, Pettersson RF, Agol VI et al. 2003 Apoptosis-related fragmentation, translocation, and properties of human prothymosin alpha. Experimental Cell Research 284 211-223.

Hashimoto $\mathbf{N}$ \& Kishimoto T 1988 Regulation of meiotic metaphase by a cytoplasmic maturation-promoting factor during mouse oocyte maturation. Developmental Biology 126 242-252.

Hengartner MO 2000 The biochemistry of apoptosis. Nature 407 770-776.

Ito J, Hirabayashi M, Kato M, Takeuchi A, Ito M, Shimada M \& Hochi S 2005 Contribution of high $\mathrm{p} 34^{\mathrm{cdc} 2}$ kinase activity to premature chromosome condensation of injected somatic cell nuclei in rat oocytes. Reproduction 129 171-180.

Kang YK, Koo DB, Park JS, Choi YH, Chung AS, Lee KK \& Han YM 2001 a Aberrant methylation of donor genome in cloned bovine embryos. Nature Genetics 28 173-177.

Kang YK, Koo DB, Park JS, Choi YH, Kim HN, Chang WK, Lee KK \& Han YM 2001b Typical demethylation events in cloned pig embryos. Journal of Biological Chemistry 276 39980-39984.

Kawahara M, Wakai T, Yamanaka K, Kobayashi J, Sugimura S, Shimizu T, Matsumoto H, Kim JH, Sasada H \& Sato E 2005 Caffeine promotes premature chromosome condensation formation and in vitro development in porcine reconstructed embryos via a high level of maturation promoting factor activity during nuclear transfer. Reproduction 130 351-357.

Kikuchi K, Naito K, Noguchi J, Shimada A, Kaneko H, Yanashita M, Aoki F, Tojo H \& Toyoda Y 2000 Maturation/M-phase promoting factor: a regulation of aging in porcine oocytes. Biology of Reproduction 63 715-722.

Kim JM, Ogura A, Nagata M \& Aoki F 2002 Analysis of the mechanism for chromatin remodeling in embryos reconstructed by somatic nuclear transfer. Biology of Reproduction 67 760-766.

Kurosaka S, Nagao Y, Minami N, Yamada M \& Imai H 2002 Dependence of DNA synthesis and in vitro development of bovine nuclear transfer embryos on the stage of the cell cycle of donor cells and recipient cytoplasts. Biology of Reproduction 67 643-647. 
Lee JH \& Campbell KHS 2006 Effects of enucleation and caffeine on maturation-promoting factor (MPF) and mitogen-activated protein kinase (MAPK) activities in ovine oocytes used as recipient cytoplasts for nuclear transfer. Biology of Reproduction 74 691-698.

Norbury C \& Nurse P 1992 Animal cell cycles and their control. Annual Review of Biochemistry 61 441-470.

Peter M, Nakagawa J, Doree M, Labbe JC \& Nigg EA 1990 In vitro disassembly of the nuclear lamina and $M$ phase-specific phosphorylation of lamins by cdc2 kinase. Cell 61 591-602.

Petters RM \& Wells KD 1993 Culture of pig embryos. Journal of Reproduction and Fertility 48 61-73.

Rudner AD \& Murray AW 1996 The spindle assembly checkpoint. Current Opinion in Cell Biology 8 773-780.

Shi W \& Haaf T 2002 Aberrant methylation patterns at the two-cell stage as an indicator of early developmental failure. Molecular Reproduction and Development 63 329-334.

Sung LY, Shen PC, Jeong BS, Xu J, Chang CC, Cheng WTK, Wu JS, Lee SN, Broek D, Faber D et al. 2007 Premature chromosome condensation is not essential for nuclear reprogramming in bovine somatic cell nuclear transfer. Biology of Reproduction 76 232-240.

Szollosi D, Czolowska R, Borsuk E, Szollosi MS \& Debey P 1998 Nuclear envelope removal/maintenance determines the structural and functional remodeling of embryonic red blood cell nuclei in activated mouse oocytes. Zygote 6 65-73.

Tani T, Kato Y \& Tsunoda Y 2001 Direct exposure of chromosome to nonactivated ovum cytoplasm is effective for bovine somatic cell nucleus reprogramming. Biology of Reproduction 64 324-330.
Tani T, Kato Y \& Tsunoda Y 2003 Reprogramming of bovine somatic cell nuclei is not directly regulated by maturation promoting factor or mitogen-activated protein kinase activity. Biology of Reproduction 69 1890-1894.

Wakayama T, Perry ACF, Zuccotti M, Johnson KR \& Yanagimachi R 1998 Full-term development of mice from enucleated oocytes injected with cumulus cell nuclei. Nature 394 369-374.

Whitworth KM, Agca C, Kim JG, Patel RV, Springer GK, Bivens NJ, Forrester LJ, Mathialagan N, Green JA \& Prather RS 2005 Transcriptional profiling of pig embryogenesis by using a $15-\mathrm{K}$ member unigene set specific for pig reproductive tissues and embryos. Biology of Reproduction 172 1437-1451.

Yin XJ, Cho SK, Park MR, Im YJ, Park JJ, Bhak JS, Kwon DN, Jun SH, Kim NH \& Kim JH 2003 Nuclear remodeling and the developmental potential of nuclear transferred porcine oocytes under delayed-activated conditions. Zygote 11 167-174.

Yoshioka K, Suzuki C, Tanaka I, Anas IMK \& Iwamura S 2002 Birth of piglets derived from porcine zygotes cultured in a chemically defined medium. Biology of Reproduction 66 112-119.

Received 27 August 2007

First decision 10 October 2007

Revised manuscript received 14 January 2008

Accepted 23 January 2008 